\title{
The Effect Of A Scientific Approach With Problem Based Learning Model To Critical Thinking And Learning Results Students IV SDN Jatikalang 1 Krian
}

\author{
Rina Astrianah, Prof. Dr. Yatim Riyanto, M.Pd. Dr. Harmanto, M.Pd. \\ Universitas Negeri Surabaya \\ Surabaya, Indonesia \\ rinaastrianah@gmail.com
}

\begin{abstract}
The fact that happened in the field during this perceived lesson IPS less able develop abilities students to thinking critically, solve the problem. Because the learning process in the classroom does not use the thinking strategy of learning. The learning process is only directed so that students can only master and memorize course material only. While critical thinking and problem-solving are indispensable in learning. So that the impact on student learning outcomes is still low. Based on the background, the researcher uses a scientific approach to learning problem-based learning model to improve critical thinking skills and student learning outcomes in IPS learning.

The purpose of this research is to improve the ability of critical thinking and learning outcomes of fourth-grade students of SDN Jatikalang 1 Krian through a scientific approach to the problem-based learning model.

Implementation of this research using experiment by using a scientific approach with problem-based learning model by using two small class, that is an experiment class and control class. The subject of this research is the students of class IV as the experimental class and class IV $B$ as the control class at SDN Jatikalang 1 Krian.

The results showed that students' critical thinking ability increased in the control class at $67.97 \%$ and $83.8 \%$ for the experimental class. While the average result of student learner in control class is $69,02 \%$ and in experimental class $85,54 \%$.

The conclusion of this research is a scientific approach to problem-based learning model can improve the ability of critical thinking and student learning outcomes in IPS learning in SDN Jatikalang 1 Krian.

For elementary school teachers, especially class IV, it is suggested to use a scientific approach with a problem-based learning model in IPS learning to improve critical thinking ability and student learning outcomes.
\end{abstract}

Keywords-Scientific Approach; Problem Based Learning; Critical Thinking; Learning Outcomes

\section{PRELIMINARY}

In learning with conventional learning model, students feel bored and lack of enthusiasm for learning because most of them are passive listening only explanation from the teacher only. At the time of the test, most of the students cannot answer and ultimately decreased student achievement. To overcome this, it is the necessary steps to optimize the teaching and learning process. What the writer will do is the transformation in the learning process to improve student achievement and the students are actively involved in the learning as the success of the goal so that the learning will be centered on the students.

The reality that occurred in the field during this perceived IPS less learning can develop students' ability to think critically, solve problems. Because in the learning process in the classroom does not use the strategy of thinking learning. The learning process is only directed so that students can only master and memorize course material only. While critical thinking and problem-solving are indispensable in learning.

Critical thinking is the cognitive ability to say things with conviction based on logical reasons and strong empirical evidence. Critical thinking is the process of systematic thinking in searching for truth and building confidence in something that is reviewed and reviewed factually and realistically. In the school environment, Johnson [1] states that critical thinking is an organized process that allows students to evaluate facts, assumptions, logic, and language underlying other people's statements.

Through critical thinking learning activities, students can understand and understand the stages in scientific thinking, have the ability to identify the subject matter, comprehensively examine an object by involving the process of active and reflective thinking, learning something systematically [2]. In addition, students can formulate the question correctly (critical question), find the origin of the problem, be able to assess an impact of events, can explain the problem and can make a simple conclusion, able to design a simple solution, and can apply the value or positive attitude of the event. So that students will be skilled in solving problems both personal and social problems.

The authors face the problem in the fourth-grade students of SDN Jatikalang 1 Krian is still low in the results of learning IPS. There needs to be an increase in the identification of economic activities in the utilization of natural resources, where the concept of cannot be understood or understood by many students. To overcome these problems, the selection of appropriate learning model should be done in order to build the spirit of student learning to be active in the learning process. 
That is creating conditions in which students can build the meaning of new materials they learn by facilitating learners to be able to do the ability to think critically and can solve problems.

From some of the above problems, the perceived problem should immediately get attention is about scientific learning that directs critical thinking skills. scientific learning is a learning that builds knowledge through scientific methods. The expected learning model is meaningful learning. One of the alternative models of learning to develop critical thinking skills and to solve problems is through a scientific approach to a problem-based learning model.

Problem Based Learning is a learning activity that can develop problem-solving skills and critical thinking because it uses real problems that are open to students in learning so that it can simultaneously build new knowledge [3]. Thus students can solve problems and acquire or build certain knowledge and simultaneously develop critical thinking skills and problemsolving skills.

The reason for this is the scientific approach because the scientific approach is a learning that encourages students to be able to perform scientific skills that are actively able to develop critical thinking and can solve problems, according to the skills in the scientific approach of observing, asking, trying, reasoning and communicating them [4]. The scientific approach is believed to be the golden bridge for the development of attitudes, skills, and knowledge.

Then the reason for the implementation of problem-based learning model that is because the problem-based learning model suitable applied to the scientific approach to improving critical thinking where the two are closely related and have the equation of stages or steps in its application. It is said to be closely related because one of the three learning models found in the scientific approach of the problem-based learning model is a model that makes the authentic situation a reference in learning to understand concepts, principles, and develop problem-solving skills. While it is said to have the equation of steps in the applying it is, step 1: orient the student to the problem (observe), step 2: organize the student to learn (ask), step 3: guide the individual or group investigation (gather information), step 4: and present the work (associate), and step 5: analyze and evaluate the problem-solving process (communicate). In addition to these reasons, the application of problem-based learning through a scientific approach is a way for teachers to create student activeness in a fun learning situation and will be an unforgettable learning experience. Thus the information or lessons can be remembered by students, so it is hoped that by using the model of student-based learning can improve the ability of critical thinking and achievement can increase.

The formulation of the problem in this research is as follows 1) Is there any influence of scientific approach with problem based learning model to critical thinking of fourth grader of SDN Jatikalang 1 Krian ?, 2) Is there any influence of scientific approach with problem based learning model toward student achievement of fourth grade of SDN Jatikalang 1 Krian?
The purpose of this research is as follows 1) To know how big influence of scientific approach with problem-based learning model to critical thinking of the fourth grader of SDN Jatikalang 1 Krian, 2) To know how big influence of scientific approach with problem-based learning model to student learning result class IV SDN Jatikalang 1 Krian.

The benefits of this study are as follows 1) For students is able to improve students' ability in solving problems with critical thinking so that the impact on improving learning outcomes. 2) For the teacher is to be the operational basis for the development of thematic learning activities in the Curriculum 2013, especially the improvement of critical thinking skills through scientific approach using problem-based learning model. 3) For the principal is able to disseminate the results of this study to elementary school teachers.4) For further research is a reference to know the problem-based learning model through a scientific approach.

\section{LiterATURE REVIEW}

In the implementation of the 2013 curriculum, the lessons are implemented using a scientific approach. Gerde [5] explains that a scientific approach is a process of asking and answering questions by using a specific set of procedures. Further, Carey [6] says that the scientific approach is quite simple, consisting of three process steps. Begin by observing carefully some parts of nature. In general, the scientific approach is a way to gain knowledge by procedures based on the scientific method. There are five steps in the scientific approach among others to observe, ask, gather information/ Tried/Experimental, associate/Rework information, and communicate.

Problem-based learning was first applied at McMaster University School of Medicine, Canada in 1969 (Rideout, 2001). The problem presented in the problem-based learning model is a contextual problem so that learners are motivated to learn. Learners discuss working in teams to solve real-world problems. The implementation of problem-based learning can challenge learners to learn more actively and actively and collaborate or work in groups to find solutions to real-world problems.

In accordance with the various definitions above, it can be concluded that the learning model is prepared so that students get important knowledge and student can critical thinking, so they are proficient in solving problems, have their own learning style and have the ability to communicate in groups. The approach used in problem-solving is a systematic approach in the learning process to face the challenges of everyday life. The syntax is 1: orient the students to the problem, step 2: organize the students to learn, step 3: guide individual and group investigations, step 4: develop and present the work, and step 5: analyze and evaluate the problem-solving process.

Critical thinking is the ability to express things with confidence and confidence based on logical and systematic reasons. Johnson [1] reveals that critical thinking is a process directed so that students can assess the fact, assumption, logic, and language that underlies the statement of others. Through activities in the process of critical thinking, students can understand and master in mastering the steps in scientific 
thinking, involving active and reflective thinking processes in studying an object, finding innovative solutions to solve a problem systematically and procedurally, developing opinions based on tangible evidence and rational reasons, and decide something with consideration of various aspects fairly and wisely.

Student learning outcomes are the values that students gain during teaching and learning activities. According to Sudjana [7], "student learning outcomes are behavioral changes as a result of learning in a broad sense covering the fields of cognitive, affective, and psychomotor." So from that sense, it can be concluded that the learning outcomes can be measured through the process and product assessment in terms of cognitive, affective, and psychomotor domains.

While Bloom explained that "learning is an activity of body and soul to lead to the development of the full human person which means related to creativity, taste, and intention. I studied more deeply, then the results of learning can be contained in the taxonomy of Bloom, which is grouped into three domains (domains) namely the cognitive domain or thinking ability, affective domain or attitude, and psychomotor or skill domains[8].

\section{METHOD}

This research uses a quasi-experiment or quasiexperimental design. The research pattern used a nonequivalent control group design. This design is similar to the pretestposttest control group design, only in this design, the experimental group or the control group is not randomly selected. The use of the design is based on a research plan using two sample classes, namely experimental class, and control class. The sample in this research is an experiment class is IVA with a number of 24 students and the control class is IVB with a number 23 student.

In general, nonequivalent control group design is described as follows.

Tabel 3.1

\begin{tabular}{|llll|}
\hline $\begin{array}{llll}\text { Kelas Eksperimen } \\
O_{1}\end{array}$ & $x$ & $O_{2}$ \\
Kelas Kontrol & $O_{3}$ & $x$ & $O_{4}$ \\
\hline
\end{tabular}

\author{
Keterangan: \\ O1n $=$ Pretest (Kelompok Eksperimen) \\ $\mathrm{O} 2 \mathrm{n}=$ Postest (Kelompok Eksperimen) \\ $\mathrm{X}=$ Treatment \\ O3n $=$ Pretest (Kelompok Kontrol) \\ $\mathrm{O} 4 \mathrm{n}=$ Pretest (Kelompok Kontrol) \\ [9]
}

The technique of collecting data in this research is observation and test. His instrument as follows 1) observation sheet, used to collect data about students' attitudes in learning. The observation sheet is based on an indicator of critical thinking. 2) written test sheets, this learning result test is an objective matter, where the test is tested before and after treatment. While the critical thinking skills test in the form of a description that will be given to the experiment class at the time of the learning process. 3) learning device sheets, Assessment is done by using a learning device and research instrument by using the validation sheet[10]. Data analysis techniques in quantitative research using statistics. Testing the hypothesis using the t-test. Before the t-test is done first tested normality and homogeneity. Teknik data analysis used there are two data analysis techniques for critical thinking skills and data analysis techniques for student learning outcomes.

Test assumption analysis, 1) normality test data, normality testing done to determine whether the data comes from the population that is normally distributed or not. Normality test of this research is done by taking data from pretest and posttest value both control and experiment. Test the normality of data in this study using Kolmogorov Smirnov test with the help of SPSS 21 For Windows software at normal significance level. 2) homogeneity test data, homogeneity test using a Levene test through Independent Sample T-Test by using SPSS 21 For Windows software. 3) hypothesis test, Ujighhipotesis with difference test of two averages (Test ti) performed on the test values of the experimental group and the control group. The test of the research hypothesis used the Independent Sample TTest used to find out whether two average came from the same population[11].

\section{RESEARCH RESUlT AND DisCUSSION}

Learning has been conducted on April 27, 2018. At the time of learning the observation result of students' critical thinking ability in each control class is; very good 1 person $(4.16 \%)$, Good 2 people $(8.33 \%)$, Good enough 17 people $(70,83 \%)$, Poor Good 3 people (12,5\%) Not Good 1 person $(4,16 \%)$. After the answer sheet of the student's work is corrected, it is obtained Not Completed $11(45,83 \%)$ people and thoroughly $13(54,16 \%)$ people.

At the time of learning the observation result of students' critical thinking ability in each control, a class is; very good 15 people $(62,5 \%)$, Good 6 people $(25 \%)$, Good enough 3 people $(12,5 \%)$, Less Good 0 person not Good 0 people. After the answer sheet of the student's work is corrected, then all students get $100 \%$ complete.

\section{Conclusions And SugGestions}

Based on the results of research and data analysis, can be presented several conclusions of research results as follows; 1) there are differences in critical thinking of students who follow the learning with the scientific approach with problembased learning model. In this case it can be seen from the students' ability to (1) define and clarify the problem of identifying central issues or issues, comparing similarities and differences, and creating and formulating questions appropriately; (2) assessing information relating to the problem of finding the causes of problem events and being able to predict further problems; (3) formulate problem solutions and make simple conclusions. 2) there are 
differences of critical thinking skill of students who follow learning with the scientific approach with problem-based learning model with lecture learning.

Based on the results of research that have been done and the results obtained, it is recommended some things as follows. 1) learning with skill aspect on the scientific approach, in observing activity should student observe an object in real. 2) scientific approach to problem-based learning model is active learning, innovative, and fun for the lover so that if executed daily with conflict issues will grow student's critical thinking ability. For that, for the teacher to apply a scientific approach to problem-based learning model to improve students' critical thinking ability.

\section{REFERENCES}

[1] S. Johnson and H. Siegel, Teaching thinking skills. Bloomsbury Publishing, 2010.
[2] Y. Ibrahim and M. Yaumi, "PembelajaranBerbasisKecerdasanJamak (Multiple Intelligences)," Jakarta: Kencana, 2013.

[3] Rusman, Model-model pembelajaran: mengembangkan profesionalisme guru. Rajawali Pers/PT Raja Grafindo Persada, 2011.

[4] S. Amri, "Pengembangan dan model pembelajaran dalam kurikulum 2013," Jakarta: Prestasi Pustaka, 2013.

[5] H. K. Gerde, R. E. Schachter, and B. A. Wasik, "Using the scientific method to guide learning: An integrated approach to early childhood curriculum," Early Child. Educ. J., vol. 41, no. 5, pp. 315-323, 2013.

[6] S. S. Carey, A beginner's guide to scientific method. Cengage Learning, 2011.

[7] N. Sudjana, Penilaian hasil proses belajar mengajar. PT Remaja Rosdakarya, 1995.

[8] I. N. S. Degeng and N. Sudana, "Ilmu pengajaran taksonomi variabel," Jakarta: Depdikbud, 1989.

[9] P. Sugiyono, "Dr. 2010," Metod. Penelit. Kuantitatif, Kualitatif, dan R\&D. Bandung CV Alf.

[10] Sugiyono, Statistika untuk Penelitian. Bandung: Alfabeta, 2012.

[11] A. Maksum, "Metodologi penelitian dalam olahraga." Surabaya: Unesa University Press, 2012. 